Ambient Science, 2020: Vol. 07(Sp1); 28-29

DOI:10.21276/ambi.2020.07.sp1.nc01

\title{
The Effect of Educational Videos on Restriction Period and Normalization Period on Physical Activity Levels in the COVID-19 Pandemic
}

\section{Yeliz Doğru \\ Health, Culture and Sports Department, İzmir Kâtip Çelebi University, İzmir, Turkey.}

\author{
Study Area: Izmir \\ Coordinated: $38.42^{\circ} \mathrm{N} 27.14^{\circ} \mathrm{E}$
}

Key words: Video Campiagn, Quarantine Period, Corona Virus.

physical activity status of individuals in the process of social isolation and normalization.

\section{Methodology:}

Fifty-two (female: 32, male: 20) volunteers living in Izmir province participated in the study. Participants were included in the study via e-mail and social media communication tool (Whats App). A two-part questionnaire including demographic information and the International Physical Activity Questionnaire was applied to all participants. It began to be implemented as of March 27 and June 1 severe restrictions in Turkey normalization steps were taken. Therefore, the participants were surveyed twice, in May covering the restriction period and in August covering the normalization period.Educational videos containing 1 hour of exercise training were sent to all participants.The trainings were sent to the participants through the digital platform.

Development studies of the International Physical Activity Questionnaire started in Geneva in 1998 and validity and reliability studies have been carried out in 12 countries. IPAQ has been developed to determine physical activity levels (Craig et al., 2003). There are eight versions of IPAQ in four short and four long forms known as telephone, interview or self-administered methods. In addition, the question types may change as 'last 7 days' or 'any week'(IPAQ,2005). In this study, the self-administered last 7 days short form of the scale was used (IPAQ Short-Form). IPAQ short form; provides information about sitting, walking, moderately vigorous activities and time spent in vigorous activities (Öztürk, 2005).The total scoring of the short form; walking is performed by calculating the total duration (minutes) and frequency (days) of moderate vigorous activity and vigorous activity (IPAQ, 2005). The sitting score, which is the sedentary behavior level, is calculated separately in scoring. The criterion for evaluating all activities is that each activity is done for at least 10 minutes at a time. A score of 'MET minutes/week' is obtained from these calculations. MAT is the metabolic equivalent and corresponds to approximately $3.5 \mathrm{ml}$ oxygen consumption per 1 MET kg. While making calculations for

*Author:yeliz.dogru@hotmail.com 
IPAQ Short-Form, a score of 'MET-minute / week' is obtained by multiplying the minute, day and MET value (multiples of resting oxygen consumption).

Following values were used for the analysis of the IP data:

$\begin{array}{ll}\text { Walking }= & 3.3 \mathrm{MET}, \\ \text { Moderate Physical Activity }= & 4.0 \mathrm{MET}, \\ \text { Severe Physical Activity }= & \text { 8.0 MET, } \\ \text { Seating }= & 1.5 \mathrm{METS} .\end{array}$

Accordingly, there are 3 levels of activity: Inactive, minimally active, very active (Özüdogru, 2013).

SPSS 22.00 program was used for statistical analysis. Descriptive statistics were shown using mean, standard deviation, minimum \& maximum. Shapiro-Wilk Test was used for the normal distribution of data. Statistical analysis was performed by Mann-Whitney U, Chi-square correlation analysis. The signif icance level was $\mathrm{p}<0.05$.

\section{Results:}

Descriptive statistics of the data are shown in Table-1.

Table-1: Descriptive statistics

\begin{tabular}{lll}
\hline Parameters & Mean \pm SD & Min-Max \\
\hline Age $(\mathrm{yr})$ & $21.6 \pm 1.3$ & $18-25$ \\
Height $(\mathrm{cm})$ & $176.5 \pm 2.5$ & $162-182$ \\
Body Weight $(\mathrm{kg})$ & $74.1 \pm 2.3$ & $54-81$ \\
BMI $(\mathrm{kg} / \mathrm{m} 2)$ & $24.1 \pm 3.8$ & $21.2-26.4$ \\
\hline
\end{tabular}

Grouping of volunteers according to their physical activity levels is given in table 2 . Accordingly, there is a significant difference between all values between the restraint period and normalization periods.

Table-2: Comparison of individuals' physical activity levels

\begin{tabular}{llll}
\hline Paramters & $\begin{array}{l}\text { Restriction } \\
\text { Period }\end{array}$ & $\begin{array}{l}\text { Normalization } \\
\text { Period }\end{array}$ & $\mathrm{P}$ \\
\hline $\begin{array}{l}\text { Severe Physical Activity } \\
\text { (min / week) }\end{array}$ & $32.21 \pm 25.22$ & $93.5 \pm 12.33$ & oo1 $^{*}$ \\
$\begin{array}{l}\text { Moderate Physical } \\
\begin{array}{l}\text { Activity (min/week) } \\
\text { Walking (min/week) }\end{array}\end{array}$ & $90.7 \pm 14.44$ & $150.95 \pm 654.6$ & oo1* $^{*}$ \\
$\begin{array}{l}\text { Total Physical Activity } \\
\text { (MET-min / week) }\end{array}$ & $541.15 \pm 165.68$ & $1523.66 \pm 1321.54$ & о03 $^{*}$ \\
\hline
\end{tabular}

\section{Discussion:}

All over the world, the Covid-19 pandemic has caused public health restrictions. In this study, it was shown that the participants were inactive during the restriction period. It was found that the physical activity levels of the participants increased during the normalization process. In the isolation process of this situation, psychological factors that may prevent physical activity may be effective (Ciddi \& Yazgan, 2020).

During the COVID-19 pandemic, the exercise that people can do outside is relatively limited. For this reason, exercises they can do at home have gained more importance. Staying active by modifying exercises at home has become more important for health. The duration of these exercises can be planned according to the age, health status and possibilities of the person (Özkan \& Diliçk,2020).

In the normalization process, it is said that outdoor activities can be done safely if the social distance rules are followed. Walking, cycling, walking and running will allow individuals to get some fresh air without coming into close contact with others. However, social distance should be taken very seriously(Blocken, 2020).

As a result, it has been shown that physical activity levels begin to increase during the normalization process. It can be said that the decreasing physical activity levels during the home restraint period stem from the measures taken against thepandemic risk

\section{References:}

Blocken, B. M. F., van Druenen, T., Marchal, T. (2020): Towards aerodynamically equivalent COVID-19 $1.5 \mathrm{~m}$ social distancing for walking and running.Questions and Answers. Website Bert Blocken, Eindhoven University of Technology (The Netherlands) and KU Leuven (Belgium)

Booth, F.W., Roberts, C. K, Laye, M. J. (2012): Lack of exercise is a major cause of chronic diseases. Com. Physiol., 2(2):1143-211.

Ciddi, P. K. \& Yazgan, E. (2020). The Effect of Physical Activity Status on Quality of Life During Social Isolation in the Covid-19 Outbreak. Istanbul Comm. Univers. J. Soc. Sci., 19(37):262-279.

Craig, C. L., Marshall, A.L., Sjostrom, M., Bauman, A.E. \& Booth, M. L. (2003). International Physical Activity Questionnaire: 12-Country Reliability and Validity. Med. Sci. Sports Exerc., 35:1381-1395.

IPAQ Research Committee Guidelines For Data Processing and Analysis Of International Physical Activity Questionnaire (2005). http://www.İpaq.Ki.Se(Accessed 11/o9/2020).

Jiménez-Pavón, D., Carbonell-Baeza, A. \& Lavie, C. J. (2020). Physical exercise as therapy to fight against the mental and physical consequences of COVID-19 quarantine: Special focus in older people. Prog. Cardiovasc. Dis.

Lauer, S. A., Grantz, K. H., Bi, Q., Jones, F. K., Zheng, Q., Meredith, H. R., et al. (2020). The incubation period of coronavirus disease 2019 (COVID19) from publicly reported confirmed cases: estimation and application. Ann. Intern. Med., 172(9):577-82.

Li, Q., Guan, X., Wu, P., Wang, X., Zhou, L., Tong, Y., et al. (2020). Early Transmission Dynamics in Wuhan, China, of Novel CoronavirusInfected Pneumonia. N. Eng. J. Med., 382(13):1199- 207.

Özkan, Ö., Diliçıkık, U. (2020). COVID-1919 What Should I Do and How to Do It in Pandemic? Med. Res. Rep., 3(S-1):172-175.

Özüdoğru, E. (2013). Investigation of the Relationship Between University Personnel Physical Activity Level and Quality of Life. Mehmet Akif Ersoy University Institute of Educational Sciences, Master Thesis, Burdur.

Wu, D., Wu, T., Liu, Q. \& Yang, Z. (2020). e SARS-CoV-2 outbreak: what we know.Int. J. Infect. Dis., S1201-9712(20)30123-30125.

Zheng, S., Fan, J., Yu, F., Feng, B., Lou, B., Zou, Q., et al. (2020). Viral load dynamics and disease severity in patients infected with SARS-CoV-2 in Zhejiang province, China, January-March 2020: retrospective cohort study. BMI, 369:m1443.

$\rightarrow$ https://www.who.int/ emergencies/diseases/novel-coronavirus-2019. $\rightarrow$ https://www.who.int/ emergencies/diseases/novel-coronavirus-2019 $\rightarrow$ https://covidig.who.int/. 